\title{
Optimization and Kinetic Study of Cellulose Hydrolysis to Glucose Catalyzed by Phosphoric Acid ( $\left.\mathrm{H}_{3} \mathrm{po}_{4}\right)$
}

\author{
Okereke Macjonathan Chimchetam ${ }^{1}$, Verla Andrew Wirnkor ${ }^{2 *}$, Duru Edbert Chidi ${ }^{3}$ \\ ${ }^{1}$ Department of Chemistry, IMSU, Owerri, Nigeria \\ ${ }^{2}$ GRACE\&CC, Department of Chemistry, IMSU, Owerri, Nigeria \\ ${ }^{3}$ Department of Chemistry, IMSU, Owerri, Nigeria
}

*Corresponding Author: Verla Andrew Wirnkor, GRACE\&CC, Department of Chemistry, IMSU, Owerri, Nigeria

\begin{abstract}
The hydrolysis of cellulose to glucose at the temperature of $100 \mathrm{o} C$ using phosphoric acid as catalyst was studied in this work. The effect of acid concentration on glucose yield with $1 \mathrm{~g}$ of biomass weight was studied at H3PO4 concentrations of $1 \%, 2 \%, 4 \%, 8 \%, 15 \%$ and $20 \%$. It was found that glucose yield is directly proportional to acid concentration, with best yield of glucose being $21 \mathrm{mg}$ in 35 minutes at acid concentration of $15 \%$. The hydrolysis could not take place at other concentrations studied. The effect of biomass weight on glucose yield was carried out with $0.5 \mathrm{~g}, 1.0 \mathrm{~g}, 1.5 \mathrm{~g}$ and $2.0 \mathrm{~g}$ of biomass. Results showed that $1.5 \mathrm{~g}$ and $2.0 \mathrm{~g}$ gave both $22 \mathrm{mg}$ of glucose, while the other biomass weights gave $0 \mathrm{mg}$. This also indicated a proportional relationship between biomass weight and glucose yields. Optimization studies were carried out using the best values of acid concentration and biomass weight. The results showed that rate of cellulose hydrolysis at these conditions was $0.957 \mathrm{mg} / \mathrm{min}$. The results obtained from this study showed that phosphoric acid is not a good catalyst for cellulose hydrolysis.
\end{abstract}

Keywords: Cellulose, Acid hydrolysis, Glucose yield, Optimization.

\section{INTRODUCTION}

As the challenges associated with non-renewable energy sources looms, a lot of research is being carried out on the conversion of biomass (cellulose) to biofuels, a renewable energy source. There is a wide variety of biomass, and composition is also diverse. Some primary components are cellulose, hemicellulose, lignin, starch, and proteins. Trees mainly consist of cellulose, hemicellulose, and lignin, and so herbaceous plants, although the component percentages differ. Different kinds of biomass have different components: grains have much starch, while livestock waste has many proteins. Because these components have different chemical structures, their reactivities are also different. From the standpoint of energy use, lignocelluloses biomass, which consists mainly of cellulose and lignin such as trees, exist in large amounts and have great potential. ${ }^{[1]}$ Cellulose is a carbohydrate of the polysaccharide group having the formular $\left(\mathrm{C}_{6} \mathrm{H}_{10} \mathrm{O}_{5}\right) \mathrm{n}$. It is the most abundant organic polymer on earth which can be can be broken down chemically into its glucose units by treating it with acids at high temperature. ${ }^{[4]}$ And then the glucose fermented and distilled to obtain a type of biofuel known as bioethanol. Although cellulose is sufficiently stable toward hydrolysis to allow it to be dyed, finished and laundered, it is susceptible to hydrolysis by acids. Acids attack the acetal linkages, cleaving the 1-4-glycosidic bonds. ${ }^{[11]}$ Numerous challenges are encountered in the course of biofuel production from cellulosic materials. The first difficulty is encountered in the pretreatment process where a lignocellulosic material is used. Pretreatment of the lignocllulosic biomass is a key step intended to render the cellulose hydrolysate more amenable and accessible, thereby increasing glucose yields. Due to its rigid structure and crystallinity, cellulose is resistant to hydrolysis. The hydrolysis of cellulose is a slow process and the extent of hydrolysis is influenced by the structural properties of the biomass substrate, such as cellulose crystallinity, surface area, degree of polymerization and porosity. ${ }^{[19]}$ In order to increase the efficiency and efficacy of the hydrolysis process, it is necessary to perform a chemical pretreatment of the biomass to modify its composite structure, thereby allowing better access to cellulose. Some chemical treatments such as with liquid ammonia and aqueous sodium hydroxide $(\mathrm{NaOH})$, are known to alter the crystalline structure of cellulose, resulting in the formation of different allomorphs that have different unit cell dimensions, chain packing schemes and hydrogen bonding relationships. ${ }^{[20]}$ The research is carried out 
to obtain the effective parameters and conditions suitable for acid hydrolysis of cellulose. In other words, the research projects the optimal conditions necessary for the cellulose hydrolysis process. These parameters include the suitable acid concentration, contact time and biomass weight at constant temperature for maximum glucose yield.

\section{MATERIALS AND MeTHODS}

\subsection{Preparation of Phosphoric Acid Solutions}

Phosphoric acid solutions $(1 \%, 2 \%, 4 \%, 8 \%, 15 \%$ and $20 \%)$ were prepared. In preparing $1 \%$ of $\mathrm{H}_{3} \mathrm{PO}_{4}, 1 \mathrm{ml}$ of $\mathrm{H}_{3} \mathrm{PO}_{4}$ was added to $100 \mathrm{ml}$ volumetric flask and the flask made up to $100 \mathrm{ml}$ mark with water. In the same manner, $2 \%, 4 \%, 8 \%, 15 \%$ and $20 \%$ were prepared by measuring $2 \mathrm{ml}, 4 \mathrm{ml}, 8$ $\mathrm{ml}$, and $20 \mathrm{ml}$ respectively into $100 \mathrm{ml}$ volumetric flask.

\subsection{Procedure for Assessing the Effect of Acid Concentration on Glucose Yield}

To washed and dried beakers $(100 \mathrm{ml}), 1 \mathrm{~g}$ of cellulose was weighed into each and $100 \mathrm{ml}$ of $1 \%, 2 \%$, $4 \%, 8 \%, 15 \%$ and $20 \%$ phosphoric acid solution was added to each of these beakers. The beakers were labelled and stirred properly in the acid solution. At this point, glass reactors were labelled and the cellulosic acid solution from the beakers transferred to them. Heating mantle was setup and the reactors heated while immersed in a beaker $(250 \mathrm{ml})$ containing some water. This heating process lasted for 35 minutes of which the very first 5 minutes ensured thermal stability between the solutions in the reactors and the water in the beaker. After this duration of time, the heating process was dismantled and $5 \mathrm{ml}$ of the heated mixture was extracted from each reactor and poured into beakers $(50 \mathrm{ml})$. Each of the heated solution in the beaker was neutralized with sodium hydrogen carbonate $\left(\mathrm{NaHCO}_{3}\right)$ in excess to ensure complete neutralization. With the aid of a glucose meter, the glucose yield was measured and recorded for each acid concentration.

\subsection{Procedure for Assessing the Effect of Biomass Weight on Glucose Yield}

This assessment was done with $15 \%$ of $\mathrm{H}_{3} \mathrm{PO}_{4}$. To washed and dried beakers $(100 \mathrm{ml}), 0.5 \mathrm{~g}, 1.0 \mathrm{~g}, 1.5$ $\mathrm{g}$, and $2.0 \mathrm{~g}$ of cellulose were weighed into each. The beakers were labeled and $100 \mathrm{ml}$ of $15 \%$ of $\mathrm{H}_{3} \mathrm{PO}_{4}$ was added to each of the beaker. The solution was stirred properly and transferred into glass reactors. A heating mantle was setup and the reactors heated for 35 minutes. The reactors were evacuated and $5 \mathrm{ml}$ extracted from each, poured into beakers $(50 \mathrm{ml})$ and neutralized with sodium hydrogen carbonate in excess. The glucose yield of each was measured and recorded using a glucose meter.

\subsection{Procedure for Assessing the Effect of Contact Time on Glucose Yield}

In order to assess the effect of time on glucose yield, $1.5 \mathrm{~g}$ of biomass was weighed into $100 \mathrm{ml}$ beakers. To each of the beakers, $100 \mathrm{ml}$ of $15 \%$ of $\mathrm{H}_{3} \mathrm{PO}_{4}$ was added and stirred. All the mixture was transferred into glass reactors and heated while immersed in a beaker containing water for the first 5 minutes for the attainment of thermal stability. The heating process continued for the next 20 minutes after which one reactor was isolated, and $5 \mathrm{ml}$ of the cellulosic-acid solution extracted from it, poured into a beaker $(50 \mathrm{ml})$ and neutralized in excess with sodium hydrogen carbonate. The glucose yield was measured and recorded. The next reactor was brought out after the next 30 minutes, neutralized and the glucose yield measured and recorded. The next reactor was brought out after the next 30 minutes, neutralized and the glucose yield measured and recorded. The other remaining reactors followed the same step after the next 20, 20 and 15 minutes time intervals.

\section{RESUltS}

The Table 1 below shows the hydrolysis of $1 \mathrm{~g}$ of cellulose by different acid concentrations of phosphoric acid and their corresponding glucose yields.

Table1. Effect of Phosphoric Acid Concentration on Glucose Yield

\begin{tabular}{|c|c|}
\hline Phosphoric Acid Concentration (\%) & Glucose Yield (mg) \\
\hline $\mathbf{1}$ & 0 \\
\hline $\mathbf{2}$ & 0 \\
\hline $\mathbf{4}$ & 0 \\
\hline $\mathbf{8}$ & 0 \\
\hline $\mathbf{1 5}$ & 21 \\
\hline $\mathbf{2 0}$ & 0 \\
\hline
\end{tabular}


Table 2 below shows the hydrolysis of different cellulose weight by $15 \%$ of $\mathrm{H}_{3} \mathrm{PO}_{4}$ and their corresponding glucose yields.

Table2. Effect of Biomass Weight on Glucose Yield

\begin{tabular}{|c|c|}
\hline Biomass Weight $(\mathrm{g})$ & Glucose Yield(mg) \\
\hline $\mathbf{0 . 5}$ & 0 \\
\hline 1.0 & 0 \\
\hline 1.5 & 22 \\
\hline $\mathbf{2 . 0}$ & 22 \\
\hline
\end{tabular}

Table 3 below shows the hydrolysis of $1.5 \mathrm{~g}$ of cellulose by $15 \%$ of $\mathrm{H}_{3} \mathrm{PO}_{4}$ and the glucose yields at different time intervals.

Table3. Effect of Contact Time on Glucose Yield

\begin{tabular}{|c|c|}
\hline Time (minutes) & Glucose Yield (mg) \\
\hline $\mathbf{2 0}$ & 0 \\
\hline $\mathbf{5 0}$ & 27 \\
\hline $\mathbf{8 0}$ & 54 \\
\hline $\mathbf{1 0 0}$ & 79 \\
\hline $\mathbf{1 2 0}$ & 101 \\
\hline $\mathbf{1 3 5}$ & 111 \\
\hline
\end{tabular}

Figure 1 below shows the plot of different glucose yields against different concentrations of phosphoric acid.

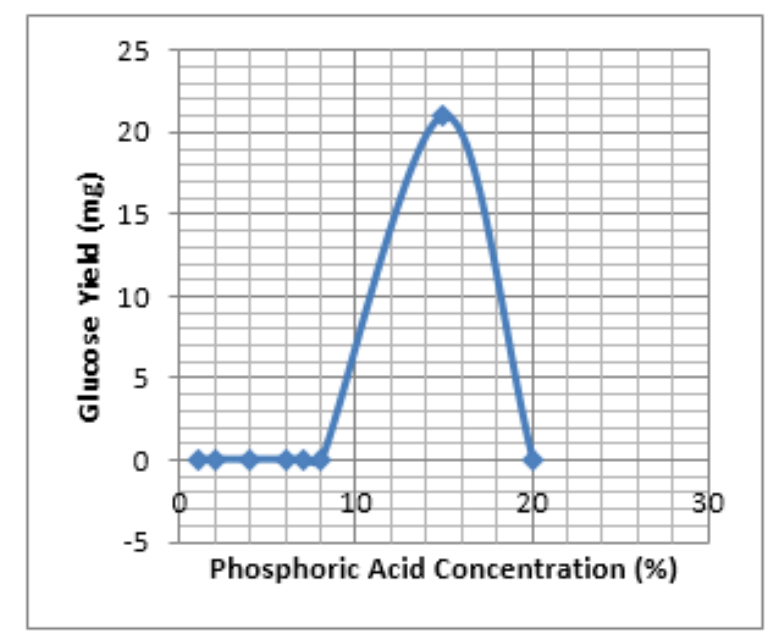

Figure1. Effect of Acid Concentration on Glucose Yield

Figure 2 below shows the plot of different glucose yields against different biomass weights.

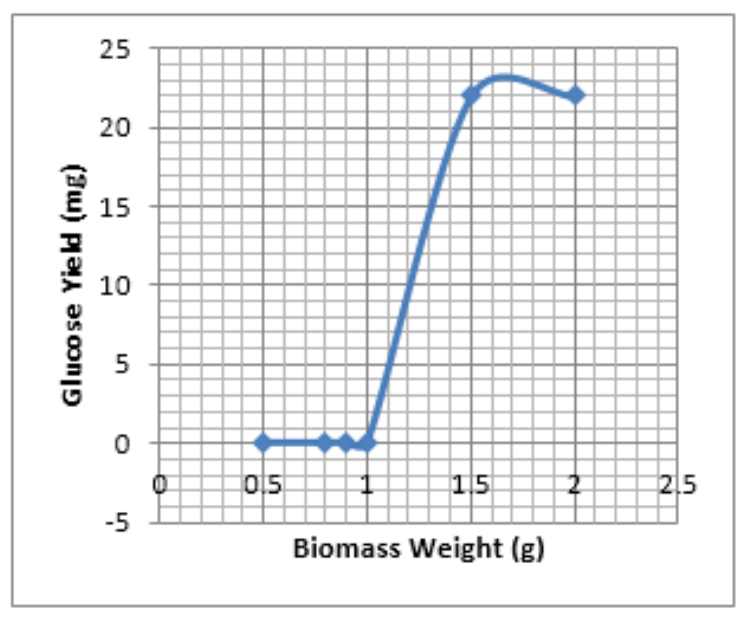

Figure2. Effect of Biomass Weight on Glucose Yield

The Figure 3 below shows the plot of different glucose yields at different time intervals. 


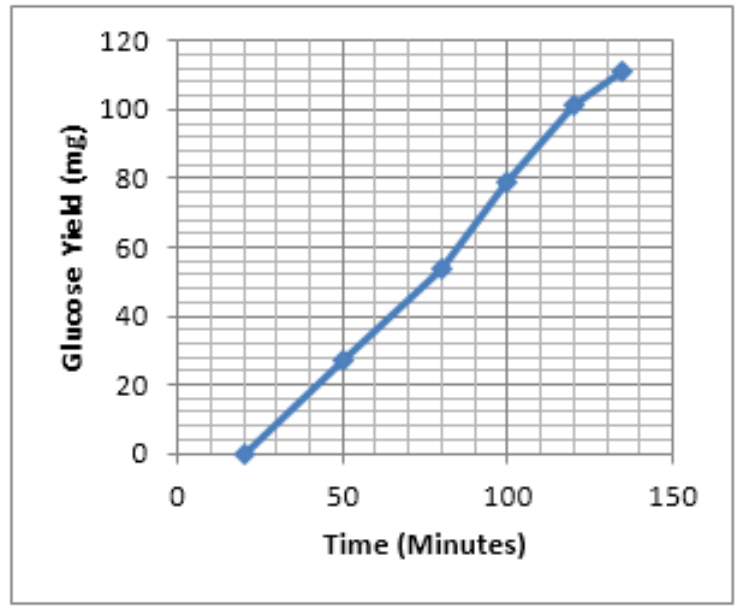

Figure3. Effect of Contact Time on Glucose Yield at Optimal Conditions.

$$
\begin{aligned}
\text { Rate of glucose yield }= & \frac{\Delta \text { Glucose Yield }(\mathrm{mg})}{\Delta \text { Time (minutes) }} \\
& =\frac{110-20}{134-40} \\
=\quad \frac{90}{94} & =0.957 \mathrm{mg} / \mathrm{min}
\end{aligned}
$$

Rate of glucose yield $=0.957 \mathrm{mg} / \mathrm{min}$

Hence, for every minute past, $0.957 \mathrm{mg}$ of glucose is formed.

\section{DISCUSSION}

In Table 1, we have a kinetic experiment on the hydrolysis of $1 \mathrm{~g}$ of biomass by phosphoric acid $\left(\mathrm{H}_{3} \mathrm{PO}_{4}\right)$ at different concentrations. The Table therefore shows the effect of acid concentration on glucose yield. We have the first acid concentration to be $1 \%$ of $\mathrm{H}_{3} \mathrm{PO}_{4}$ which resulted to $0 \mathrm{mg}$ of glucose yield. This shows that at this concentration $(1 \%), \mathrm{H}_{3} \mathrm{PO}_{4}$ cannot hydrolyze. The concentration was increased a unit further to $2 \%$. The glucose yield at this concentration was $0 \mathrm{mg}$ which shows also the inability of $\mathrm{H}_{3} \mathrm{PO}_{4}$ to hydrolyze at $2 \%$ concentration. At $4 \%$ of $\mathrm{H}_{3} \mathrm{PO}_{4}$, we have also the glucose yield to be $0 \mathrm{mg}$. Phosphoric acid also could not hydrolyze at this concentration level. The concentration was made to increase four units further to $8 \%$. And just like the previous concentration levels, the glucose yield was also $0 \mathrm{mg}$. This also signifies the inability of $\mathrm{H}_{3} \mathrm{PO}_{4}$ to hydrolyze at the experimented concentration level. The concentration was increased to $15 \%$, a six unit increase. At this concentration (i.e. 1:15), we had a low $21 \mathrm{mg}$ of glucose yield. The concentration was increased to $20 \%$ and glucose yield dropped to $0 \mathrm{mg}$. Normally an increase in glucose yield was expected as there was an increase in the concentration of $\mathrm{H}_{3} \mathrm{PO}_{4}$. But the reverse was the case. The explanation for this is that at $20 \%$ of $\mathrm{H}_{3} \mathrm{PO}_{4}$, there might have been a possible decomposition of the glucose formed into an undesirable by-product like hydroxymethylfurfural (HMF). Since the rate of glucose decomposition in acidic medium is directly proportional to concentration regardless of acid type ${ }^{[21]}$, it then means that hydrolysis of $1 \mathrm{~g}$ cellulose with $20 \% \mathrm{H}_{3} \mathrm{PO}_{4}$ is not feasible. In other words, the acidic level is too high for $1 \mathrm{~g}$. The results here show that glucose yield is directly proportional to acid concentration. They also confirm the weak and triprotic nature of $\mathrm{H}_{3} \mathrm{PO}_{4}$, because at $15 \%$ level of concentration as against $1 \mathrm{~g}$ of cellulose, we could only obtain $21 \mathrm{mg}$ of glucose. Finally, they show that the best glucose yield on the hydrolysis of $1 \mathrm{~g}$ of cellulose with phosphoric acid can only be obtained within the range of $12 \%-17 \%$ concentration of $\mathrm{H}_{3} \mathrm{PO}_{4}$ which should result to $14 \mathrm{mg}-16 \mathrm{mg}$ of glucose by extrapolation as shown in Figure 1. As can be seen in Figure 1 also, beyond $15 \%$ of $\mathrm{H}_{3} \mathrm{PO}_{4}$, a decrease in glucose yield resulted. This decrease could have been also as a result of glucose decomposition in acidic medium. Hence, $15 \%$ of $\mathrm{H}_{3} \mathrm{PO}_{4}$ is the best acid concentration in the hydrolysis of $1 \mathrm{~g}$ of cellulose, being the concentration that gave the best glucose yield.

Table 2 shows a kinetic experiment on the effect of biomass weight in the hydrolysis reaction of cellulose catalyzed by $15 \%$ of phosphoric acid. The first hydrolysis was done with $0.5 \mathrm{~g}$ of cellulose and the glucose yield was gotten to be $0 \mathrm{mg}$. This shows the non-feasibility status of the hydrolysis of $0.5 \mathrm{~g}$ of cellulose by $15 \%$ concentration of $\mathrm{H}_{3} \mathrm{PO}_{4}$ due to high acidity level of the system. Hence, the formed glucose might have been decomposed in the system. At $1 \mathrm{~g}$ of cellulose, the glucose yield read 
$0 \mathrm{mg}-\mathrm{a}$ kind of anomaly that is explained by contact time. The biomass weight was increased to $1.5 \mathrm{~g}$ and at this weight; the glucose yield read $22 \mathrm{mg}$. In order to confirm the trend of this effect, a further increase in weight was done to $2.0 \mathrm{~g}$ of biomass. And at this biomass weight, glucose yield also read 22 $\mathrm{mg}$. It was expected that an increase be seen in the glucose yield, but it remained constant. The overall results obtained from the study of this parameter show a proportional relationship that exists between biomass weight and glucose yield. Figure 2 also shows the graphical relationship of biomass weight and acid concentration to be proportional. Though, $1.5 \mathrm{~g}$ and $2.0 \mathrm{~g}$ of cellulose gave same $22 \mathrm{mg}$ of glucose, $1.5 \mathrm{~g}$ was selected as the best biomass weight in studying the rate of glucose yield since its more economical.

The rate of glucose yield studied using the best conditions were shown in Table 3 . The study was done at time intervals of $20 \mathrm{~min}, 50 \mathrm{~min}, 80 \mathrm{~min}, 100 \mathrm{~min}, 120 \mathrm{~min}$ and $135 \mathrm{~min}$. And the glucose yields at these time intervals were $0 \mathrm{mg}, 27 \mathrm{mg}, 54 \mathrm{mg}, 79 \mathrm{mg}, 101 \mathrm{mg}$ and $111 \mathrm{mg}$ respectively. This shows that glucose yield is time dependent. As time increases, glucose yield increases as shown in Figure 3. With the aid of Figure 3, the rate of glucose yield was calculated to be $0.957 \mathrm{mg} / \mathrm{min}$. This shows that phosphoric acid is a very slow catalyst for cellulose hydrolysis.

Results obtained from this research work prove that acid hydrolysis of cellulose is quite dependent on some parameters. These parameters are; system's acidity (type and concentration of acid catalyst), biomass' or substrate's properties (amount and particle size) and contact time. ${ }^{[22]}$

\section{CONCLUSION}

With the significance of the discussed results above, it is very obvious that the hydrolyzing ability of phosphoric acid is very low. The use of $\mathrm{H}_{3} \mathrm{PO}_{4}$ as a catalyst in cellulose hydrolysis wastes a lot of time and energy and therefore economically non feasible. In addition, the catalytic usefulness of $\mathrm{H}_{3} \mathrm{PO}_{4}$ in cellulose hydrolysis is barely appreciated due to what is believed to be caused by its acidic strength. If it is assumed that cellulose is hydrolyzed directly to glucose, it will result in a very low glucose yield in phosphoric acid than in sulphuric acid, nitric acid or hydrochloric acid at the same hydrogen ion concentration, temperature, cellulose weight and time. ${ }^{[23]}$ Phosphoric acid is therefore not a good catalyst for cellulose hydrolysis. And it is therefore not recommended for future cellulose hydrolysis reaction.

\section{REFERENCES}

[1] Ogi, T., (2002), Biomass Handbook, Japan Institute of Energy Ed., pp. 2-6

[2] Crawford, R.L., (1981), Lignin Biodegradation and Transformation, John Wiley and Sons, New York, pp. 2-3

[3] Romeo and Tony, (2008), Bacterial Biofilms, Berlin: Springer, pp. 258-263.

[4] Klemm, Dieter, Heublein, Brigitte, Fink, Hans-Peter, Bohn and Andreas, (2005), Cellulose: Fascinating Biopolymer and Sustainable Raw Material, Angew. Chem., Ed. 44 (22).

[5] Encyclopaedia Britannica, (2008), Cellulose, Encyclopaedia Britannica Online, pp. 5.

[6] Bishop and Charles, A., (2007), Vacuum Deposition onto Webs, films, and Foils, Berlin Springer, pp. 165.

[7] Deguchi, S., Tsujii, K., Horikoshi and Koki, (2006), Cooking Cellulose in Hot and Compressed Water, J. Chem. Communications, Vol. (31), pp. 3293.

[8] Ding, S.Y. and Himmel, M.E., (2003), The Maize Primary Cell Wall Microfibril: a New Model Derived from Direct Visualization, J. Ag Food Chem., Vol. (54), pp. 597-606.

[9] Andersson, S., Serimaa, R., Paakkari, T., Saranpää, P. and Pesonen, E., (2003), Crystallinity of Wood and the Size of Cellulose Crystallites in Norway spruce (Picea abies), J. Wood Sci., Vol. (49), pp. 531-537.

[10] Fan, L.T., Lee Y.H. and Beardmore, D.H., (1980), Mechanism of the Enzymatic Hydrolysis of Cellulose: Effect of Major Structural Features of Cellulose on Enzymatic Hydrolysis, Biotechnol Bioeng., Vol. (23), pp. 177-199.

[11] Hall, M., Bansal, P., Lee, J.H., Realff, M.J. and Bommarius, A.S., (2010), Cellulose Crystallinity - a Key Predictor of the Enzymatic Hydrolysis Rate, FEBS J., Vol. (277), pp. 1571-1582.

[12] Chen, H., (2014), Biotechnology of Lignocellulpse: Theory and Practice, Chemical Industry Press and Springer Science Beijing. pp. 26, 30, 35, 42- 43.

[13] Brian, H., Davidson, Jerry P., Mark, F., Davis, and Bryon, S.D., (2013), Plant Cell Walls: Basic Structure Chemistry Accessibility and the Influence on Conversion; Oak Ridge National Laboratory and Bioenergy Centre and National Renewable Energy Laboratory, $1^{\text {st }}$ Edition, Golden and Bioenergy Science Centre Oak Ridge USA, pp. 27. 
[14] Harmsen, P.F.H., Huijgen, W.J.J., Bermudez, L.L.M. and Bakker, R.R.C., (2010), Literature Review of Physical and Chemical Pretreatment Process of Ligniocellulosic Biomass, Energy Research Centre of the Netherlands. pp 1, 8-13.

[15] Musatto, S.I. and Texeira, J.A., (2010), Lignocelluloses as Raw Material in Fermentation Processes, Institute of Biotechnology and Bioengineering, University of Minho, Portugal.

[16] Somma, D., lobkowicz, H., Deason, J.P., (2010), Growing America's Fuel: An Analysis of Corn and Cellulosic Ethanol Feasibility in the United States, Clean Techn. Environ Policy, pp. 373-380.

[17] David, P., Alison, M., Megan, A.T., Marissa, K., Gillian, S.P., Robert, M., Joanna, K. and Tim K., (2008), Biofuel Impacts on World Food Supply: Use of Fossil Fuel, Land and Water Resources, J. of Open Access Energies, pp. 42.

[18] Nathan, S.M., (2006), Cellulosic ethanol-Biofuel Beyond Corn, J. of Purdue University, pp. 1-2.

[19] Nobles, D., Romanovicz, D., and Brown, R.M. Jr., (2001), Plant Physiol, Island Press, Washington, pp. 29, 127

[20] Weimer, P.J., French, A.D. and Calamari, T.A. Jr., (1991), Differential Fermentation of Cellulose Allomorphs by Ruminal Cellulolytic Bacteria, Angew. Chem., Ed. 44 (22), pp. 138.

[21] Laura, K., (2012), Dilute Acid Catalysed Hydrolysis of Cellulose - Extension to Formic Acid, B.Sc. Dissertation, University of Oulu, Finland.

[22] Taherzadeh and Karimi, (2007), Bioethanol Review, BioResources, Vol 2 (3), pp. 477.

[23] Yao-Bing and Yao, (2013), Hydrolysis of Cellulose to Glucose by Solid Acid Catalysts, Green Chem., Vol. 15, pp. 1195, 1104.

Citation: Verla Andrew Wirnkor, et.al, "Optimization and Kinetic Study of Cellulose Hydrolysis to Glucose Catalyzed by Phosphoric Acid ( H $\left._{3} \mathrm{po}_{4}\right)$ )", International Journal of Advanced Research in Chemical Science, 7(7), pp. 27-32. DOI: https:// doi.org/10.20431/2349-0403.0707003

Copyright: () 2020 Authors, this is an open-access article distributed under the terms of the Creative Commons Attribution License, which permits unrestricted use, distribution, and reproduction in any medium, provided the original author and source are credited. 